\title{
ŽALJENJA: FENOMENOLOGIJA, KONCEPTUALIZACIJE I ISTRAŽIVANJA
}

\section{Katica LACKOVIĆ-GRGIN}

Zadar

UDK: 159.942.4

Pregledni rad

Primljeno: 22. 10. 2011.

Žaljenje je neugodno kognitivno i emocionalno stanje koje nastaje kao posljedica pogrešaka u akciji ili zbog nepoduzimanja akcije na putu prema ostvarenju cilja. Filozofske, ekonomske i psihologijske teorije govore o prirodi i uzrocima žaljenja, za koje je utvrđeno da je jedna od najčešćih negativnih emocija i da predstavlja univerzalno ljudsko iskustvo. Uspiešno suočavanje sa žaljenjem poboljšava kognitivne procese, a neuspiešno suočavanje loše utječe na motivaciju cilju usmjerenih aktivnosti i dovodi do životnoga žalienja te oštećuje fizičko i mentalno zdravlje. Na osnovi uzroka i konteksta u kojem se doživljava, žaljenje je moguće (i potrebno) razlikovati od srodnih konstrukata, kao što su osjećaj krivnje, razočaranje i kajanje. U tome važnu ulogu ima količina u akciju uloženoga napora i osjećaj odgovornosti za neuspieh akcije. Deskriptivne studije pokazuju da se najveća žaljenja javljaju zbog obrazovanja, karijere, ljubavnih odnosa, roditeljstva i samopoimanja, posebice ako su u nekim od tih područja ispitanici vidjeli dobre prilike koje nisu iskoristili. Razina žaljenja ovisi o važnosti životnih područja, ali i o socijalnim i temporalnim usporedbama. Kad u stariiih osoba pregled života rezultira žaljenjem, njegov će intenzitet biti manji ako se uspoređuju sa sličnima sebi (lateralno) ili s lošijima od sebe (silazno). Pri samoregulaciii žaljenja uloga internalne kontrole razlikuje se s obzirom na dob. Iznose se i ideje za moguća dalinja istraživanja žaljenja.

Ključne riječi: pregled života, žaljenje, suočavanje, odgovornost, napor, razočaranje, socijalno uspoređivanje, samoregulacija 
Razvojni psiholozi ističu da je ono što ljudi žele u životu i načini kako oni to postižu snažan poticaj njihovu razvoju tijekom životnog vijeka (Baltes i Baltes, 1990.; Heckhausen, 1999.). U našim radovima o samoregulaciji razvoja tijekom adolescentne i odrasle dobi (Lacković-Grgin, 2005., 2007.; Lacković-Grgin i Penezić, 2010.; Penezić i Lacković-Grgin, 2001.), između ostaloga, isticali smo značenje ciljeva kao organizatora samoregulacije.

Ostvarenje ciljeva povezano je sa životnim zadovoljstvom, dok poteškoće u njihovu ostvarenju, izražene u pogreškama, neispunjenjima i neuspjehu, generiraju osjećaj žaljenja. Žaljenje je intenzivnije ako pojedinac nije ostvario cilj u koji je uložio dosta vremena i energije. Zato za prevenciju žaljenja treba znati kada valja odustati od nekoga cilja. Uporno inzistiranje na neostvarivim ciljevima dovodi do stresa te onemogućuje odabir novih ciljeva (Klinger, 1977.; King i Hicks, 2007.).

Odabiranje, mijenjanje i ostvarivanje ciljeva ovisi o jednoj od temeljnih značajki ljudskoga ponašanja, u usporedbi s drugim vrstama, a to je njegova velika fleksibilnost. Prema Baltesu i Baltes (1990.), fleksibilnost i uspješno upravljanje životom osiguravaju tri ključna procesa: selekcija, optimizacija i kompenzacija gubitaka/pogrešaka. Navedeni procesi mogu se aktivirati u svim razdobljima života, posebice u onima koje nazivamo tranzicijskima. Životne tranzicije generiraju potrebu za odabiranjem i mijenjanjem ciljeva zbog bioloških prisila (npr. opadanja nekih resursa, pojave bolesti), kao i zbog sociokulturnih prisila (promjene društvenih pravila odnosno razvojnih zadataka, promjene kulturnog okruženja). U takvim okolnostima mnogi odrasli ljudi prepoznaju da njihov izbor životnoga puta nije u skladu s njihovim novim potrebama, vrijednostima i željama. To ih potiče na rekapitulaciju dotadašnjega života (Staudinger, 2001.) pri čemu nerijetko shvate da žale zbog onog što imaju (jesu) ili zbog onog što su propustili imati (biti). Kad dožive žaljenje zbog onog što su učinili, nerijetko se javlja i žaljenje zbog onoga što su propustili učiniti. Na primjer, žena u braku nezadovoljna odnosom supruga prema sebi, može početi žaliti što je ranije propustila udati se za drugoga muškarca koji joj je nudio brak. Čini se da ćemo zbog negativnih ishoda više žaliti kad možemo lako zamisliti eventualne bolje ishode.

Rekapitulacija i procjena života u adolescentnoj i odrasloj dobi ima različite svrhe, odnosno funkcije. Osnovna svrha jest uvid u sebe samog i kritičko preispitivanje sebe (Staudinger, 2001.). Druga je svrha korekcija životnoga puta. Empirijski je dokazano da žaljenja zbog /ne/učinjenog u srednjoj dobi potiču korektivna ponašanja (Stewart i Vandewater, 1999.). 
DRUŠ. ISTRAŽ. ZAGREB GOD. 21 (2012), BR. $3(117)$

STR. $651-670$

LACKOVIĆ-GRGIN, K.: ŽALJENJA:...
Ona su u toj dobi efikasnija nego u starijoj životnoj dobi i nerijetko dovode do raznih "osvježenja" u obiteljskom i profesionalnom životu. Zbog generativnosti u odrasloj dobi, dolazi do progresivnoga vraćanja svijesti na prošla iskustva, posebice na neriješene probleme iz prošlosti. Rezultati rekapitulacije života mogu biti funkcionalni i disfunkcionalni. Ovi potonji upućuju na to da postoji odnos između pregleda prošloga života i žaljenja zbog učinjenih izbora ili propusta. Valja se prisjetiti da su raniji autori (npr. Erikson, 1963.; Butler, 1974.) smatrali kako je rekapitulacija života karakteristična za ljude starije životne dobi, dok kasniji autori (npr. Levinson, 1978.) tvrde da je ona moguća i ranije. Može se pretpostaviti da se s dobi mijenjaju domene života na koje se rekapitulacija odnosi kao i sadržaji žaljenja i njihov intenzitet.

Prema Havighurstovoj razvojnoj teoriji (1953.), životni zadaci povezani su sa životnom dobi, odnosno s biološkim i sociokulturnim prisilama. Oni određuju i rokove izvršenja, zbog čega ljudi percipiraju da u njihovim životima postoji ono što zovemo krajnjim rokom za ostvarenje nekih ciljeva. Ako pojedinac na vrijeme angažira prikladne mehanizme regulacije, može, prije isteka krajnjeg roka, ostvariti svoje ciljeve. Nakon isteka krajnjeg roka to više nije izgledno, zbog čega slijede negativne posljedice. U jednom istraživanju odraslih ljudi, oko 50 posto ispitanika izvijestilo je o negativnim posljedicama propuštanja krajnjeg roka (Settersten i Hagestad, 1996.a, 1996.b). Kad se procijeni da se zbog propuštanja krajnjeg roka cilj više neće moći ostvariti, javit će se osjećaj žaljenja.

Ima više opisa žaljenja, a jedna od mogućih definicija opisuje žaljenje kao "neugodno kognitivno i emocionalno stanje koje nastaje pri procjeni da smo neku akciju izveli pogrešno ili pri procjeni da nešto što nam je bilo važno nismo učinili" (Landman, 1993., 36). Ako je žaljenje posljedica pogrešaka u realizaciji kratkoročnih ciljeva, ono obično potiče korektivne akcije. Zbog toga se u novijoj literaturi naglašava motivacijsko značenje žaljenja, koje, potičući korektivne akcije, pridonosi promjenama životnih okolnosti pojedinca (Zeelenberg i Pieters, 1999.). Na primjer, kad student na specijalizaciji za neurokirurga u jednom roku nije položio važan ispit, on će žaliti i početi intenzivnije učiti za drugi ispitni rok. Međutim, ako se osoba ne ponaša korektivno do krajnje predviđenog roka za ostvarenje cilja, ona će od njega morati odustati.

Odustajanje od cilja vrlo je bolno iskustvo, jer osoba shvaća da njezine sposobnosti i znanja u postojećim okolnostima više ne daju nadu za buduće dostignuće. U takvom će se slučaju javiti osjećaj životnoga žaljenja. On može potaknuti kompenzacijske aktivnosti, pa osoba odabire neki srodan cilj. Nažalost, ljudi često ne mogu ublažiti ili ukloniti žaljenje, jer za 
DRUŠ. ISTRAŽ. ZAGREB GOD. 21 (2012)

BR. $3(117)$

STR. $651-670$

LACKOVIĆ-GRGIN, K. ŽALJENJA:... to ne posjeduju odgovarajuće strategije. Na te je poteškoće upozorio Alexander Graham Bell, tvrdeći da "kad se jedna vrata zatvore, druga se otvore: no mi tako često dugo gledamo sa žaljenjem u zatvorena vrata, da ne vidimo ona koja su za nas otvorena" (prema Inman, 2007., 19). Zato iskustvo žaljenja može trajati vrlo dugo.

U literaturi je tema žaljenja relativno česta, jer je žaljenje sveprisutno ljudsko iskustvo. Jedno istraživanje o intenzitetu i frekvenciji negativnih emocija (straha, ljutnje, razočaranja i drugih) pokazuje da je žaljenje najintenzivnija negativna emocija, a da se, po frekvenciji, samo anksioznost nalazi ispred žaljenja (Saffrey i Roese, 2006., prema Zeelenberg i Pieters, 2007.). Davno je utvrđeno da su ljudi skloniji sjećati se neuspjeha nego uspjeha (Zeigarnick, 1927., prema Petz, ur., 2004.), a i da im je, ubrzo nakon izbora između raznih mogućnosti, privlačnije ono što nisu izabrali (Carmon i sur., 2003.).

Porast interesa za žaljenje ilustrira podatak o čak pedesetak milijuna "klikova" na tu riječ na Googleu, a neki bilježe i oko 370 knjiga u čijem se naslovu nalazi riječ žaljenje (Inman, 2007.). Mnoge od tih knjiga pripadaju popularnoj literaturi o samopomoći (Roese, 2005.), što upućuje na primijenjeno značenje istraživanja žaljenja. Pretraživanjem baza podataka od 1945. do 2005. godine, Zeelernberg i Pieters (2007.) utvrđuju rapidan porast radova o žaljenju nakon 1990. godine. Radovi pripadaju različitim znanstvenim područjima, a zanimljivo je da vremensku "prednost" u istraživanjima, pred psihologijom, ima ekonomija.

\section{TEORIJSKI PRISTUPI ŽALJENJU}

U ekonomiji, žaljenja se ispituju u proučavanju potrošačkoga i poslovnoga ponašanja ljudi, njihovih odluka i izbora te u situacijama neučinjenih ili krivih odluka i izbora (Zeelenberg i Pieters, 2007.). Žaljenja se istražuju i u medicini, u kojoj postoji interes za prihvatljivost žaljenja kod donošenja medicinskih odluka, a konstruiraju se i skale za njihovo mjerenje (Djulbegovic i sur., 1999.; Brehaut i sur., 2003.). U suvremenoj neuroznanosti provode se eksperimentalna istraživanja značenja orbitofrontalnoga korteksa u doživljaju žaljenja (Camille i sur., 2004.), a u zdravstvenoj psihologiji žaljenja se ispituju u vezi s preventivnim zdravstvenim ponašanjem (Chapman i Coups, 2006.). U psihologiji, osim područja emocija i motivacije, žaljenjem se bave još neke psihologijske discipline. Tako, na primjer, u međukulturnoj psihologiji ispituju se žaljenja zbog činjenja i nečinjenja u raznim kulturama (Gilovich i sur., 2003.), a klinički psiholozi istražuju odnos žaljenja i depresije te anksioznosti (Chase i sur., 2010.). U zadnjih desetak godina u razvojnoj se psihologiji ispituje razvoj žaljenja, s obzirom 
DRUŠ. ISTRAŽ. ZAGREB GOD. 21 (2012), BR. $3(117)$

STR. $651-670$

LACKOVIĆ-GRGIN, K.: ŽALJENJA:... na to da procjena posljedica akcija i neakcija, kao i zamisli o budućnosti, ovise o razini kognitivnog razvoja. Utvrđeno je da se, kronološki gledano, žaljenje javlja kasnije od drugih negativnih emocija, jer se usporedbe onog što jest i što bi moglo biti javljaju oko sedme godine života (Guttentag i Ferrell, 2004.). Nadalje, u psihologiji životnoga vijeka istražuju se mogućnosti kontrole životnih žaljenja u osoba različite dobi, relacije životnih žaljenja i kvalitete života tijekom odrasle dobi te zaštitna uloga socijalnih usporedbi u suočavanju sa žaljenjem u odrasloj dobi.

U tim se istraživanjima rabe teorijske perspektive koje su se razvijale iz filozofskih spekulacija o prirodi i uzrocima žaljenja, kao i na osnovi nekih istraživačkih rezultata. Pravci filozofskih razmišljanja o žaljenju bili su različiti. Jedan pravac naglašava da je žaljenje kognitivno "opterećena" emocija, jer da bi se ono pojavilo, osoba mora misliti o svojim izborima i neizborima, o svojim akcijama i neakcijama, kao i o njihovim posljedicama (Hampshire, 1960.). Kognitivne procjene nabrojenoga za žaljenje su mnogo važnije nego što je to s nekim drugim negativnim emocijama (npr. ljubomorom i ljutnjom). Drugi pravac filozofskih razmišljanja bavio se problemima odnosa žaljenja i vlastite odgovornosti ljudi za ono što im se događa (Taylor, 1985.). Ovaj je smjer razmišljanja potaknuo brojna istraživanja o odnosima odgovornosti i žaljenja. Njihovi rezultati pridonijeli su drukčijem definiranju žaljenja i njegovu razlikovanju od nekih drugih negativnih emocija.

Filozofske rasprave o žaljenju naišle su na dobar prijam kod kognitivistički orijentiranih psihologa, posebice onih koji su se bavili emocijama i stresom (Lazarus, 1966., 1993.). Psiholozi koji se bave mišljenjem suprotnom činjenicama (engl. counterfactual thinking) žaljenje proučavaju s obzirom na odluke u donošenju kojih su ljudi zaokupljeni mislima o tome što bi se moglo dogoditi ako djeluju, odnosno ako ne djeluju. Također, kad se odluka ne pokazuje dobrom s obzirom na njezine posljedice, javljaju se zamisli "što bi bilo da sam ...", pa i to kognitivno iskustvo postaje dio žaljenja (Kahneman, 1995.). Uz žaljenje vezuju se specifične negativne emocije, kao što su strah, ljutnja, razočaranje (Gilovich i sur., 1998.). Nadalje, socijalno-kognitivni teoretičari tumače da stvari zbog kojih osoba žali mogu biti posljedica njezina namjernoga djelovanja, ali i socijalnih okolnosti koje osoba ne može kontrolirati. Logično je pretpostaviti da će intenzitet žaljenja ovisiti o tome je li ono posljedica vlastita djelovanja ili se javilo zbog nepovoljnih okolnosti u kojima se akcija odvijala.

Unutar raznih područja istraživanja pojavili su se i razni teorijski pristupi žaljenju. Jedni se nalaze u literaturi o donošenju odluka u ekonomiji, gdje se u početku mislilo da kupci 
DRUŠ. ISTRAŽ. ZAGREB GOD. 21 (2012),

BR. 3 (117),

STR. $651-670$

LACKOVIĆ-GRGIN, K.: ŽALJENJA:... svoje odluke donose tako da izračunaju maksimum mogućega žaljenja za svaki izbor, nakon čega izabiru opciju s najnižom količinom žaljenja (Lee, 1971.). Kasnije, ekonomski pristupi žaljenju sve češće naglašavaju da pri odluci osoba može žrtvovati neki dobitak, ako misli da kasnije zbog toga neće žaliti, odnosno da anticipacija budućega žaljenja utječe na aktualni izbor (Bell, 1982.). I posljedice izbora rezultiraju žaljenjem kad osoba zamišlja da bi njezina sadašnja situacija bila bolja da je $u$ prošlosti izabrala nešto drugo. Rana definicija žaljenja u okviru ekonomskoga pristupa, u usporedbi sa psihologijskim definicijama, pojednostavnjena je zbog oslanjanja na empirijske podatke prikupljene $u$ proučavanju ponašanja u igrama na sreću, a glasi da je "žaljenje razlika u vrijednosti između imovine koja se aktualno ima i više razine imovine koja bi se postigla drugim mogućnostima" (Bell, 1982., 963). Prema tom shvaćanju, žaljenje se neće pojaviti ako osoba nije informirana o ishodu odbačenih alternativa. Istraživanja su samo djelomice potvrđivala navedena teoretiziranja o žaljenju, a počelo se shvaćati i da te teorije pojednostavnjuju problem žaljenja. U novije vrijeme pripadnici ekonomskoga pristupa, pod utjecajem psihologijskih istraživanja mišljenja suprotnog činjenicama, sve više prihvaćaju da su za žaljenje važna pravila po kojima se generiraju mogućnosti, te posljedice uspoređivanja aktualnih događaja s onima koji su se mogli dogoditi. Takva proširena gledišta ekonomskoga pristupa pokazuju se produktivnima u istraživanjima razina žaljenja, jer omogućuju proučavanja raznih putova prema istom ishodu, odnosno različitih proturječnih mogućnosti koje induciraju različite razine žaljenja. Ove konceptualne promjene utjecale su na razvoj eksperimentalnih paradigmi u proučavanju žaljenja, koje su omogućile nove spoznaje o ovoj funkcionalnoj emociji o kojoj ovise izbori naših ciljeva i naša usmjerenost na kratkoročne i dugoročne ishode.

Na rezultatima spomenutih eksperimentalnih istraživanja razvila se nova teorija regulacije žaljenja (Zeelenberg i Pieters, 2007.). Ovi autori žaljenje opisuju kao "emociju samooptuživanja kad ljudi utvrde kako bi njihova sadašnja situacija mogla biti bolja da su u prošlosti drukčije odlučili" (str. 4). Smatraju da se žaljenje javlja kao posljedica pogrešaka u akciji ili zbog neakcije te da ono predstavlja i determinantu ponašanja koja dovode do niza poboljšanja kognitivnih procesa. Kao averzivno iskustvo, žaljenje motivira ljude na regulaciju pomoću koje mogu uvećati ishode svojih akcija na kraću ili na dužu stazu. Ono se može reducirati na dva načina: 1. ponašajno (djeluje se prema izbjegavanju ili smanjenju žaljenja, pa tako osoba može, zbog prestanka romantične veze, žaljenje regulirati traganjem za novim partnerom); 2 . kognitivno (oso- 
DRUŠ. ISTRAŽ. ZAGREB GOD. 21 (2012), BR. $3(117)$

STR. $651-670$

LACKOVIĆ-GRGIN, K.: ŽALJENJA:... ba događaj reinterpretira u novom svijetlu, misli optimistično o budućnosti i slično). U ovome dijelu teorija regulacije žaljenja ne nudi osobitu novost, jer podsjeća na strategije suočavanja usmjerenog na problem i suočavanja usmjerenog na emocije (Lazarus i Folkman, 1984.). Prema teoriji regulacije žaljenja, ono može biti povezano s prošlosti (retrospektivno žaljenje) i s budućnosti (anticipirano ili prospektivno žaljenje). Ova podjela izaziva sporenja, jer se neki pitaju je li anticipirano žaljenje uopće emocija ili je to samo kognitivno predviđanje emocije (Frijda, 2004.). Autori teorije odgovaraju da eksperimentalna istraživanja indiciraju da je donošenje odluka povezano s emocijom anticipiranoga žaljenja, posebice kad su odluke teške i jako važne za osobu koja ih donosi. Ističe se da anticipirano žaljenje može promovirati tendenciju izbjegavanja rizika, ali i tendenciju traženja rizika (Zeelenberg i Pieters, 2004.). Koja će od ove dvije tendencije prevladati, ovisi o predviđanju ishoda akcije.

Autori teorije regulacije žaljenja upućuju na nekoliko strategija za regulaciju anticipiranoga žaljenja: 1 . treba donositi kvalitetne odluke služeći se pamćenjem i traganjem za relevantnim informacijama; 2 . ponekad je dobro odgoditi odlu$\mathrm{ku}$, ali odgađanje ne bi trebalo trajati predugo; 3 . valja povećati opravdanost odluke, pri čemu je vrlo važna konzistencija namjernoga ponašanja, jer promjenjivost i brzopletost obično dovode do više žaljenja; 4. ponekad treba za odluku zbog koje bi se moglo žaliti prebaciti odgovornost na one koji su uključeni u situacije u kojima se odlučuje; 5 . osigurati reverzibilnost odluke, jer ako se odluka ili njezine posljedice mogu obrnuti, anticipirat će se manje žaljenja; 6. ako je moguće, dobro je da ishod neizabranih opcija ostane nepoznat, da ne bi uspoređivanje odabranog i neodabranog izazivalo žaljenje; 7. valja unaprijed prihvatiti žaljenje u onim situacijama u kojima nije važna naša odluka (Zeelenberg i Pieters, 2007.).

Ako se nakon odluke doživjelo žaljenje, njega se može regulirati na više načina. Spomenuti autori navode pokušaje opovrgavanja ili obrtanja odluke, nalaženje dodatnih rezona za nju i za ponašanje koje je uslijedilo, poricanje odgovornosti za odluku ili njezino prebacivanje na nekoga drugog, ponovno procjenjivanje odabrane mogućnosti ili "posrebrenje" (engl. silver linking) pogreške zbog koje se žali. Nadalje, mogu se rabiti obrambeni mehanizmi kao što su poricanje i potiskivanje. Efikasnost nekih od nabrojenih strategija bile su predmetom istraživanja, ali rad na njihovoj evaluaciji tek predstoji.

Suprotno ovom teorijskom stajalištu, $u$ teoriji intenziteta žaljenja Beike i sur. (2009.) pretpostavljaju da će osjećaj žaljenja biti veći kad se percipira gubitak povoljnih prilika nego kad se zamišljaju buduće povoljne prilike. Gubitak povoljnih 
DRUŠ. ISTRAŽ. ZAGREB GOD. 21 (2012)

BR. $3(117)$

STR. $651-670$

LACKOVIĆ-GRGIN, K.: ŽALJENJA:... prilika ovi autori određuju kao neželjene ishode koji su se mogli izbjeći ili spriječiti prilikom njihova događanja. I ovi se autori u svojem teoretiziranju oslanjaju na rezultate nekih istraživanja. Snyder (2002.) nalazi da zamišljanje budućih povoljnih prilika i nevidljivi načini dostignuća u budućnosti proizvode nadu, a ona uklanja ili slabi žaljenje. Značajan faktor intenzivnijega žaljenja zbog prošlih pogrešaka subjektivni je osjećaj da prošlost nije psihološki zaključena. Zbog tog osjećaja osobe u žarište pozornosti stavljaju svoje ranije doživljene neugodne emocije uz neprestano "prežvakavanje" neugodnoga događaja (Beike i Wirth-Beaumont, 2005.). Utvrđena je značajna povezanost nezaključene prošlosti sa smanjenim samopoštovanjem (Beike, Kleinknecht i Wirth-Beaumont, 2004., prema Beike i sur., 2009.), što navodi na pretpostavku da je ona povezana i sa snažnim žaljenjem. Princip gubitka dobrih prilika, kojim se objašnjava žaljenje, potvrdili su nalazi da ljudi kad izgube dobru priliku ne vjeruju u novu priliku za realizaciju željenoga, odnosno vjeruju da neće moći ostvariti željeno samopoimanje (Markus i Nurius, 1986.). Kad ljudi vjeruju u dostignuće željenoga samopoimanja, oni ga nastoje postići. Ako u tome ne uspiju, pokušavaju zadržati prošlo samopoimanje, jer gubitak prošloga samopoimanja izaziva intenzivno žaljenje.

Teoriju intenziteta žaljenja njezini su autori provjeravali u nekoliko studija. Potvrdilo se da ljudi najviše žale zbog ishoda koji su nepopravljivi te da percepcija gubitka najboljih prošlih prilika izaziva intenzivnije žaljenje nego zamišljanje propuštanja budućih dobrih prilika (Beike i sur., 2009.). Budući da nema podataka o provjerama ove teorije od drugih autora, čini nam se da bi postavke ove teorije valjalo dalje provjeravati.

Teoretiziralo se i o pitanjima što i zbog čega ljudi žale, što su najčešća područja žaljenja, i koliko žaljenje traje.

\section{GDJE, KADA I ZAŠTO SE JAVLJAJU ŽALJENJA}

Paralelno s teorijskim razmatranjima i eksperimentalnim istraživanjima organizirana su i neeksperimentalna, deskriptivna istraživanja, u kojima se nastojalo otkriti u kojim područjima života i zašto ljudi žale, zbog čega najviše žale, jesu li žaljenja kulturalno univerzalna te postoje li dobne i spolne razlike $u$ žaljenjima. U studiji mladih i osoba srednje i starije dobi sudionicima je postavljeno pitanje što bi učinili da mogu ponovno proživjeti svoj život (Kinnier i Metha, 1989.). U sve tri dobne skupine najveći postotak ispitanika naveo je da bi povećali svoju edukaciju, da bi bili asertivniji i preuzimali više rizika u životu te provodili više vremena sa svojom obitelji. Isto je pitanje bilo postavljeno i nadarenima iz poznate Termano- 
DRUŠ. ISTRAŽ. ZAGREB GOD. 21 (2012), BR. $3(117)$

STR. $651-670$

LACKOVIĆ-GRGIN, K.: ŽALJENJA:... ve longitudinalne studije kad su bili $\mathrm{u}$ dobi od oko sedamdeset godina (Hattiangandi i sur., 1995.). U nabrajanju onoga što bi htjeli promijeniti 54 posto nadarenih navelo je više onih područja na kojima nisu bili dovoljno aktivni negoli područja akcija zbog kojih žale. U kategoriji neakcija najviše nadarenih navelo je da bi postigli više obrazovanje, da bi bili asertivniji, imali bolje socijalne odnose i provodili više vremena s obitelji. U kategoriji akcija 12 posto je navelo da su prerano sklopili brak i prekasno prestali pušiti i piti te da je bilo previše radnoga stresa. Treća kategorija obuhvaćala je navode koje je dalo 34 posto nadarenih, a koji su bili dvosmisleni sa stajališta dihotomije akcija - neakcija (npr. odgajao bi svoju djecu na drukčiji način, bio bih manje egocentričan i slično). Na osnovi metaanalize 11 radova o najvećim žaljenjima, Roese i Summerville (2005.) utvrdili su da se ona odnose na područja obrazovanja, karijere, ljubavnih veza, roditeljstva i samopoimanja. Ta su žaljenja bila najveća na onim područjima na kojima su ljudi vidjeli najviše zgodnih prilika, tj. izgleda za rast samopoimanja. Kad je propuštenih prilika više, žaljenje je intenzivnije nego kad je propuštenih prilika malo. Općenito, navedeni autori tvrde da ljudi više žale zbog neakcija nego zbog akcija zato što su neakcije otvorene prema mogućnostima zamišljanja povoljnih prilika.

$\mathrm{Na}$ osnovi teorije regulacije žaljenja Zeelenberga i Pietersa (2007.), krenulo se u provjeravanje ranijih istraživačkih nalaza na nacionalnom uzorku u SAD-u. Formulirano je nekoliko radnih hipoteza, testiranje kojih je djelomično potvrdilo postavke navedene teorije (Morrison i Roese, 2011.). Između ostaloga, potvrdilo se da je žaljenje mnogo intenzivnije kad su ishodi osobno jako važni, što potvrđuju nađene spolne razlike. Žene kojima su socijalni odnosi važniji nego muškarcima najviše žale zbog ljubavnih i obiteljskih odnosa. Muškarci najviše žale zbog karijere ili edukacije. Pokazalo se da Amerikanci s višom razinom obrazovanja imaju najviše žaljenja povezanih s karijerom. U pilot-studiji provedenoj na uzorku američkih žena, Metha i sur. (1989.) ispitivali su njihova žaljenja i prioritete. Našli su da žene iz manje prestižnih zanimanja često žale zbog propuštenih prilika u obrazovanju, dok domaćice i one s puno djece prioritet daju obiteljskom životu, a žale zbog samodiscipline više nego zaposlene žene. Za razliku od ranijih studija $u$ istraživanju Morrisona i Roese (2011.), nije se pokazala razlika u žaljenju između akcija i neakcija, nego su ta žaljenja ekvivalentna. Također se nalazi da vrijeme utječe na žaljenje u smislu da su žaljenja zbog akcija kratkotrajna, a zbog neakcija su ona dugotrajna, što se poklapa s nalazima Gilovich i Medvec (1994.). Suprotno ranijim nalazima da se najviše žali zbog nedovoljnog obrazovanja, na- 
DRUŠ. ISTRAŽ. ZAGREB GOD. 21 (2012),

BR. 3 (117),

STR. $651-670$

LACKOVIĆ-GRGIN, K. ŽALJENJA:... cionalna studija pokazuje da Amerikanci najviše žale zbog romantičnih odnosa, a iza toga zbog obiteljskoga područja. Iako bi se ove razlike mogle pripisati promjenama u vrijednostima koje se događaju u američkom društvu, njih u prvom redu valja pripisati razlikama u uzorcima. U metaanalizi koju smo spomenuli rezultati su dobiveni $u$ ispitivanjima studenata koledža, dok je najnovija studija provedena na reprezentativnom uzorku odraslih Amerikanaca. No nisu različiti uzorci jedini razlog nesuglasnih nalaza, već su to i različiti načini ispitivanja žaljenja. Neki su se koristili telefonskom anketom i direktno pitali ispitanike o njihovim žaljenjima zbog akcija i zbog neakcija u dosadašnjem životu (Morrison i Roese, 2011.). Drugi su žaljenja pokušali identificirati indirektno, pitanjem o tome što bi osobe, da ponovo žive, promijenile u svojem životu a da riječ žaljenje uopće nisu rabili (Kinnier i Metha, 1989.). Tražilo se i da ispitanici ispišu specifična žaljenja i da procjene zbog čega najviše žale, pri čemu su najveća žaljenja trebali detaljno opisati. Budući da vrijeme žaljenja utječe na njegov intenzitet, neki istraživači pitanje o žaljenju ograničili su samo na vrijeme od protekloga tjedna (Gilovich i Medvec, 1994.). Tako postavljeno pitanje rezultiralo je podjednakim brojem navođenih žaljenja zbog akcija i zbog neakcija, što se razlikovalo od navođenja žaljenja tijekom cijeloga života. Ako se žaljenje zbog neakcija u dugoj vremenskoj perspektivi pokazalo češćim, istraživanja valja usmjeriti na kognitivne procese koji pridonose dužem zadržavanju žaljenja zbog neakcija.

Glede univerzalnosti žaljenja potvrđene su pretpostavke da su ona raširena u cijelome svijetu. Analizirajući sadržaj web-stranice (RegretsOnly.com) u svojoj knjizi, Cadish (2001., 2) tvrdi da žaljenja "transcendiraju dob, spol, kulturu, rasu, religiju, jezik, socijalni status i geografsku lokaciju".

\section{ŽALJENJE I SRODNI KONSTRUKTI}

Pošto je u psihologiji postignut konsenzus oko definicije da je žaljenje "psihološki fenomen koji povezuje kognicije i emocije" (Wrosch i J. Heckhausen, 2002., 341), započele su rasprave s ciljem da se žaljenje razluči od srodnih emocionalnih stanja. U literaturi se favorizira koncept žaljenja kao širok pojam za nezadovoljstvo s nekim ishodom, iako se u specifičnim slučajevima može raditi o osjećaju krivnje, o razočaranju, kajanju, pa i o tuzi.

Za nalaženje distinkcije između žaljenja i nabrojenih emocionalnih stanja teoretičari upućuju na važnost uzroka žaljenja i na kontekst događaja procjena kojih rezultira žaljenjem. Temeljno pitanje o uzrocima žaljenja na raznim područjima života jest žale li ljudi više zbog onog što su učinili, ali to nisu željeli učiniti, ili zbog onoga što nisu učinili, ali su to željeli 
DRUŠ. ISTRAŽ. ZAGREB GOD. 21 (2012), BR. 3 (117)

STR. $651-670$

LACKOVIĆ-GRGIN, K.: ŽALJENJA:... učiniti. Takva su pitanja, u svojoj studiji ispitanicima prosječne dobi od 40 godina, postavljali Gilovich i Medvec (1994.). Zbog onoga što nisu učinili, a to su željeli učiniti, žaljenje je izrazilo 75 posto ispitanika. No ovi rezultati dopuštaju alternativnu interpretaciju, tj. da ispitanici više žale zbog akcija, ali da možda veći broj njih nije u njima griješio. Istraživači su zato dodatno tražili da ispitanici slične dobi odgovore na pitanje o najvećem žaljenju zbog akcija i najvišem žaljenju zbog neakcija. Na ta je pitanja 70 posto ispitanika navelo najveće žaljenje zbog najveće pogreške koju su učinili. Navedeni su istraživači intervjuirali i treću skupinu ispitanika te analizirali transkripte tih intervjua. Otkrili su da je osjećaj osobne odgovornosti ključan za iskustvo žaljenja, o čemu govore i rezultati nekih ranijih istraživanja (Frijda i sur., 1989.). Zbog nepoduzimanja akcija žalilo je 63 posto, a zbog akcija 37 posto ispitanika. Čini se da kad ljudi nešto ne učine pripisuju sebi veću odgovornost nego kad u akciji pogriješe. Kad sebi pripisuju odgovornost za pogreške, moguće je da će se javiti grižnja savjesti (Taylor, 1985.).

U traganju za valjanim odgovorima na pitanje žale li ljudi više zbog akcija ili zbog neakcija važna je vremenska perspektiva, odnosno radi li se o specifičnim, kratkotrajnim žaljenjima ili pak o životnim žaljenjima. Ljudi se lakše suočavaju s kratkotrajnim žaljenjima jer rabe korektivne akcije. No neke osobe nastavljaju činiti istu vrstu pogrešaka zbog kojih žale, pa s vremenom počinju doživljavati osjećaj krivnje ili anksioznost, svjesni vlastite odgovornosti za takvo činjenje. To je prisutnije u religioznih osoba, a povezuje se sa shvaćanjem grijeha (Taylor, 1985.). Žaljenje pak nastaje u skladu sa starogrčkim shvaćanjem grijeha kao "pucnja u prazno", tj. kao krive odluke u određenom trenutku, koja ne izaziva osjećaj krivnje. Povezivanje pogrešaka s nekom moralnom notom rezultirat će osjećajem krivnje ili srama, a ne žaljenja. Kad je žaljenje povezano s pogreškama samoaktualizacije, ono je zapravo više osjećaj tuge ili čežnje (Markus i Nurius, 1986.). Neki zato govore o čežnjivom ili nostalgičnom žaljenju, posebice kad priča o neakciji nikad ne prestaje (Beike i Wirth-Beaumont, 2005.), ili kad loše posljedice nečinjenja postanu vidljive tek kasnije u životu. Nostalgična su žaljenja češća u starosti, kao i u ljudi zapadnih zemalja, u čijim se kulturama forsira akcija i životna utrka. Nečinjenje može izazvati veće žaljenje zato što ono odstupa od kulturnog obrasca po kojemu je važno uvijek biti ispred drugih.

U kontekstu još nekih determinanti žaljenja, ispitivano je i razočaranje. Preciznije, pokušalo se provjeriti kakva je uloga napora što ga osoba ulaže u postizanje nekoga cilja. Ispitivala se uloga fizičkih i mentalnih napora, ali i neka psihološka ula- 
DRUŠ. ISTRAŽ. ZAGREB GOD. 21 (2012),

BR. 3 (117),

STR. $651-670$

LACKOVIĆ-GRGIN, K.: ŽALJENJA:... ganja (na primjer, povjerenje u bliskom odnosu) ili financijska ulaganja (na primjer, količina uloženoga novca). Utvrdilo se da razočaranje nastaje pošto je $u$ postizanje nekog ishoda $u$ ložen velik napor, a ishod je negativan, odnosno cilj nije ostvaren (van Dijk i sur., 1999.). Žaljenje pak nastaje kad je u postizanje cilja uloženo malo napora, a cilj se nije ostvario. Između žaljenja i razočaranja ima dosta sličnosti. Obje su emocije negativne i obje proizlaze iz procesa usporedbe onoga što se željelo, onoga što se dogodilo i onoga što se moglo dogoditi. No između njih postoje razlike zbog kojih ih se može smatrati odvojenim emocijama (Zeelenberg i sur., 1998.). Oni su provjeravali razlikuje li se žaljenje od razočaranja po antecendentama, po fenomenologiji i po ponašajnim posljedicama.

Glede antecendenata utvrđeno je da: 1. žaljenju prethodi malo uloženoga napora, a razočaranju prethodi velik napor; 2. žaljenje je više povezano s vlastitim djelovanjem, a razočaranje više s djelovanjem drugih; 3 . razočaranje je povezano s visokim rezultatima na sljedećim dimenzijama: neočekivanost, motivacijsko stanje, legitimnost, djelovanje okolnosti, dok je žaljenje povezano s visokim rezultatima na dimenzijama: mogućnost kontrole i vlastito djelovanje.

Razlike u fenomenologiji žaljenja i razočaranja utvrđene su kod pet ključnih komponenti emocija o kojima govori Plutchik (1980.), našli su Roseman i sur. (1994.). To su razlike u osjećajima, mislima, akcijskim tendencijama, akcijama i emocionalno-motivacijskim ciljevima. Studija Zeelenberg i sur. (1998.) također je potvrdila te razlike. One su bile najizraženije $\mathrm{u}$ akcijskim tendencijama i emocionalno-motivacijskim ciljevima. Preciznije, našli su da žaljenje i razočaranje možemo razlikovati po tome što žaljenje uključuje intenzivnije osjećaje da se moglo učiniti bolje, zatim misli o tome kako se pogriješilo i razmišljanja kako ispraviti pogreške i iskoristiti drugu priliku.

Na ponašajnom planu razlike se ogledaju u načinima kako žaljenje i razočaranje utječu na naše izbore i na akcije. Žaljenje uključuje snažnije djelovanje prema ispravljanju pogrešaka vezanih uz aktualna, ali i uz prošla iskustva. U proučavanjima potrošačkoga ponašanja ljudi Zeelenberg i Pieters (1999.) nalaze da razočaranje rezultira pritužbama za lošu servisnu uslugu i obavještavanjem drugih konzumenata istovrsne usluge o vlastitu lošem iskustvu, dok žaljenje rezultira izborom druge tvrtke za servisne usluge. Visoka razina žaljenja ne rezultira pričanjima drugima o vlastitu lošem iskustvu. Opisano ponašanje razočaranih osoba poklapa se s ranije utvrđenim značajem odgovornosti za pojavu razočaranja. Ponašajne razlike između razočaranja i žaljenja ogledaju se i u situacijama donošenja odluka. Uz razočaranje češće se javlja 
DRUŠ. ISTRAŽ. ZAGREB GOD. 21 (2012), BR. $3(117)$

STR. $651-670$

LACKOVIĆ-GRGIN, K.: ŽALJENJA:... povećana odbojnost prema rizicima i preferiranje sigurnih alternativa nego uz žaljenje. U eksperimentalnim je situacijama utvrđeno i to da razočaranje prate osjećaji slabosti i tendencija odmicanja od situacija koje su ga prouzročile, što $u$ krajnjem slučaju dovodi i do odustajanja od cilja.

$\mathrm{Na}$ kraju valja istaknuti, da ako se u slučajevima donošenja odluka o izboru između nekih mogućnosti odabrana mogućnost pokaže neuspješnom, započinje proces zamišljanja što bi bilo da je izbor bio drukčiji. Ako je informacija o drugoj, boljoj, mogućnosti dostupna samo pojedincu, usporedba koju on provodi njegova je privatna stvar, pa ona rezultira žaljenjem. Međutim, u socijalnim situacijama koje uključuju informacije o boljim ishodima drugih osoba koje su birale bolju opciju može kod pojedinca koji je nije izabrao izazvati zavist. Coricelli i Rustichini (2010.) eksperimentalno potvrđuju da je upravo socijalno uspoređivanje ključno za razlikovanje žaljenja i zavisti, koji potječu iz istog izvora.

\section{SOCIJALNI I RAZVOJNI ASPEKTI ŽALJENJA}

Opažanja u svakodnevnom životu, kao i empirijske studije, upućuju na to da ljudi koji ne uspijevaju regulirati intenzitet žaljenja imaju manju kvalitetu života i niže životno zadovoljstvo, pa i lošije tjelesno i mentalno zdravlje (Wrosch i sur., 2005.). Odrasli ljudi tijekom života reguliraju žaljenja na načine koje smo opisali. Samozaštitni procesi, prema teoriji kontrole životnoga vijeka (Heckhausen i Schulz, 1995.), između ostaloga su reorganizacija ciljeva i aspiracija, odnosno sekundarna kontrola. Ona omogućuje realizaciju ciljeva na nižoj razini od željene, pa može reducirati žaljenje. Procesi samoregulacije odvijaju se u socijalnom kontekstu koji je utjecao na izbor ciljeva, na njihovo /ne/ostvarenje, pa i na njihovu reorganizaciju. Osobe iz socijalne okoline, osim što ponekad izravno djeluju na samoregulaciju žaljenja, čine to i neizravno zahvaljujući procesu socijalnog uspoređivanja. Oni koji žale nerijetko se uspoređuje s drugima na relevantnim područjima života. U ovisnosti o prirodi socijalne usporedbe, intenzitet žaljenja može se smanjiti ili povećati. Utvrđeno je da ljudi koje žale zbog neuspjeha na području vrlo relevantnom za njihovo samopoimanje osjećaju veće žaljenje kad se uspoređuju sa sebi bliskima nego sa socijalno udaljenim osobama (Tesser, 1988.; Tesser i sur., 1988.). Kad su oni s kojima se uspoređujemo slični nama (lateralne usporedbe) ili slabiji od nas na relevantnom području (silazne usporedbe), uspoređivanje može umanjiti neugodne emocije vezane uz iskustvo neuspjeha (Heckhausen i Brim, 1997.). Usporedbe s boljima od sebe povećavaju neugodne emocije povezane s neuspjehom (Aspinwall i Taylor, 1993.). 
DRUŠ. ISTRAŽ. ZAGREB GOD. 21 (2012)

BR. $3(117)$

STR. $651-670$

LACKOVIĆ-GRGIN, K.: ŽALJENJA:...
Silazne socijalne usporedbe pokazale su se učinkovitima $\mathrm{u}$ ispitivanjima osoba koje su doživjele neuspjehe i/ili gubitke. I u laboratorijskim eksperimentima, u kojima su sudionici dobivali informacije o vlastitim dostignućima i o dostignućima drugih, pokazalo se da silazne socijalne usporedbe reduciraju žaljenje među sudionicima (van Harreveld i sur., 2008.). Kad su $\mathrm{u}$ ispitivanjima starijih osoba rabljeni samoizvještaji o utjecaju intenzivnoga žaljenja na poteškoće spavanja, također se potvrdilo da se, zahvaljujući silaznim socijalnim usporedbama, smanjio negativan efekt žaljenja na spavanje (Wrosch i sur., 2007.). Ako se starije osobe uspoređuju s pripadnicima svoje dobne skupine manje intenzivno žale, a takav se učinak nije iskazao u mlađih odraslih (Bauer i sur., 2008.). Uspoređivanje starijih osoba s generaliziranim drugima dovodi do osjećaja socijalnoga degradiranja (Heckhausen i Brim, 1997.).

U potrazi za razvojnim promjenama $\mathrm{u}$ žaljenjima, kao i za procesima koji utječu na njihov intenzitet, razvojni psiholozi oslanjali su se na teorijske pristupe o samoregulaciji razvoja. Rezultati dobiveni u okviru teorije kontrole životnoga vijeka pokazali su da kompenzatorna sekundarna kontrola štiti emocionalnu dobrobit starijih, ali ne i mladih žena (Heckhausen i sur., 2001.). Kad je u procesu samoregulacije žaljenja uzrok atribuiran niskoj internalnoj kontroli, bio je povezan s visokim intenzitetom žaljenja samo kod starijih, dok je kod mlađih bio povezan s manjim intenzitetom žaljenja (Wrosch i Heckhausen, 2002.). Stariji su izvijestili da imaju manje internalne kontrole nad dugotrajnim žaljenjima. Samozaštita dobrobiti i tjelesnoga zdravlja odustajanjem od ciljeva ili njihove reorganizacije također se pokazuje efikasnom kod starijih, ali ne i kod mlađih odraslih (Wrosch i sur., 2003.).

S obzirom na to da su navedena istraživanja imala za cilj dobne usporedbe, valja naglasiti da bi utvrđene razlike mogle objasniti i neki situacijski faktori, odnosno subjektivne i objektivne prilike u kojima ljudi žive. Zato su uslijedile provjere doprinosa što ga razlikama u dobrobiti i zdravlju daju okolnosti. Utvrđen je njihov skromni doprinos, što bi se moglo objasniti činjenicom da su nepovoljne okolnosti slabo korelirane s dobi, odnosno da se nepovoljni životni događaji zbivaju cijeloga životnog vijeka i da samozaštitni mehanizmi pomažu ljudima svih dobi suočavati se s nepovoljnim okolnostima. No priroda tih mehanizama mijenja se $\mathrm{u}$ smislu da ono što je efikasno za starije ne mora biti takvo i za mlađe odrasle, i obrnuto. Jedno naše istraživanje pokazalo je da posljedice temporalnog uspoređivanja koje ljudi rabe pri samoevaluaciji svojih dostignuća, zdravlja i socijalne efikasnosti s dobi postaju sve nepovoljnije zbog čega stariji ljudi sve rjeđe rabe tu vrstu uspoređivanja (Ćubela Adorić i Lacković-Grgin, 2003.). 
DRUŠ. ISTRAŽ. ZAGREB GOD. 21 (2012), BR. $3(117)$

STR. $651-670$

LACKOVIĆ-GRGIN, K.: ŽALJENJA:...
Pretjerano temporalno uspoređivanje s prošlim sobom u starijoj dobi može generirati ili održavati žaljenja jer upućuje na gubitke resursa za korekcije ili za nova dostignuća.

U navedenim su istraživanjima upotrijebljeni transverzalni nacrti. Usporedbe raznih dobnih skupina nisu dale mogućnost uvida u promjene značenja socijalnih usporedbi za intenzitet žaljenja tijekom odrasle dobi. Jedna longitudinalna studija pokazuje da se kod ispitanika s dobi događa pomak prema silaznim socijalnim usporedbama, što objašnjava dobne razlike u intenzitetu žaljenja tijekom vremena (Bauer i sur., 2008.). Ranije su, na osnovi istraživačkih rezultata, Wrosch i sur. (2005.) zaključili da u starijoj dobi oslobađanje od visokih ciljeva i odabir dohvatljivih ciljeva ima značajnu adaptivnu vrijednost.

\section{UMJESTO ZAKLJUČKA}

Radovi u ranijoj i recentnoj časopisnoj literaturi posvećeni žaljenju, s obzirom na njihov broj i vrstu, omogućuju sistematizaciju sadržaja koji dotiču teorijske, konceptualne i istraživačke probleme. Kako u Hrvatskoj takvih istraživanja nema, ponuđena sistematizacija može kod naših znanstvenika pobuditi interes za ovu relevantnu temu. Mogla bi se organizirati višedisciplinarna istraživanja o varijablama koje utječu na pojavu žaljenja i na motivacijske procese što ih žaljenje pokreće te ispitati uloga nekih karakteristika ličnosti koje pridonose pojavi žaljenja, kao što su npr. perfekcionizam, pesimizam i samostišavanje. Pozornost zaslužuju specifična žaljenja na onim područjima života koja se rijetko navode u dosadašnjoj literaturi, s obzirom na to da su neka područja istaknuta samo u nekim, kraćim, razdobljima života, u kojima posebne okolnosti pridonose sklonosti ljudi evaluaciji prijeđenog puta i planiranju budućega života, pri čemu može doći do interferencije novih i prošlih ciljeva i do žaljenja koja otežavaju prilagodbu. Razvojni psiholozi mogu u okviru suvremenih razvojnih teorija i teorija žaljenja pokušati organizirati longitudinalne studije koje bi pratile skupine ispitanika tijekom nekoliko tranzicijskih razdoblja, s posebnim obzirom na procese koji pridonose prevenciji životnih žaljenja. Naravno, izazovno je i kreiranje novih metodoloških rješenja za ispitivanje žaljenja.

\section{LITERATURA}

Aspinwall, L. G. i Taylor, S. E. (1993.), Effects of Social Comparison Direction, Threat, and Self-Esteem on Affect, Self-Evaluation, and Expected Success. Journal of Personality and Social Psychology, 64 (5): 708-722. doi:10.1037//0022-3514.64.5.708

Baltes, P. B. i Baltes, M. M. (1990.), Psychological Perspectives in Successful Aging: The Model of Selective Optimisation with Compensation. U: P. B. Baltes i M. M. Baltes (ur.), Successful Aging: Perspectives from Behavioral Science (str. 1-34), New York, Cambridge University Press. 
DRUŠ. ISTRAŽ. ZAGREB GOD. 21 (2012), BR. $3(117)$

STR. $651-670$

LACKOVIĆ-GRGIN, K.: ŽALJENJA:...
Bauer, I., Wrosch, C. i Jobin, J. (2008.), I'm Better Off Than Most Other People: The Role of Social Comparisons for Coping with Regret in Young Adulthood and Old Age. Psychology and Aging, 23 (4): 800-811. doi:10.1037/a0014180

Beike, D. R., Markman, K. D. i Karadogan, F. (2009.), What We Regret Most are Lost Opportunities: A Theory of Regret Intensity. Personality and Social Psychology Bulletin, 35 (3): 385-397.

Beike, D. R. i Wirth-Beaumont, E. T. (2005.), Psychological Closure as a Memory Phenomenon. Memory, 13 (6): 574-593. doi:10.1080/0965 8210444000241

Bell, D. E. (1982.), Regret in Decision Making Under Uncertainty. Operations Research, 30 (5): 961-981. doi:10.1287/opre.30.5.961

Brehaut, J. C., O'Connor, A. M., Wood, T. J., Hack, T. F., Siminoff, L., Gordon, E. i Feldman-Stewart, D. (2003.), Validation of a Decision Regret Scale. Medical Decision Making, 23 (4): 281-292. doi:10.1177/ 0272989X03256005

Butler, R. (1974.), Successful Aging and the Role of the Life Review. Journal of the American Geriatric Society, 22: 529-535.

Cadish, B. (2001.), Damn!: Reflections on Life's Biggest Regrets, Kansas City, Andrew McMeel Publishing.

Camille, N., Coricelli, G., Sallet, J., Pradat-Diehl, P., Duhamel, J. R. i Sirigu, A. (2004.), The Involvement of the Orbitofrontal Cortex in the Experience of Regret. Science, 304 (5674): 1167-1170. doi:10.1126/science. 1094550

Carmon, Z., Wertenbroch, K. i Zeelenberg, M. (2003.), Option Attachment: When Deliberating Makes Choosing Feel Like Losing. Journal of Consumer Research, 30 (1): 15-29. doi:10.1086/374701

Chapman, G. B. i Coups, E. J. (2006.), Emotions and Preventive Health Behavior: Worry, Regret, and Influenza Vaccination. Health Psychology, 25 (1): 82-90. doi:10.1037/0278-6133.25.1.82

Chase, H. W., Camille, N., Michael, A., Bullmore, E. T., Robbins, T. W. i Sahakian, B. J. (2010.), Regret and the Negative Evaluation of Decision Outcomes in Major Depression. Cognitive, Affective and Behavioral Neuroscience, 10 (3): 406-413. doi:10.3758/CABN.10.3.406

Coricelli, G. i Rustichini, A. (2010.), Counterfactual Thinking and Emotions: Regret and Envy Learning. Philosophical Transactions of the Royal Society, 365 (1538): 241-247. doi:10.1098/rstb.2009.0159

Ćubela Adorić, V. i Lacković-Grgin, K. (2003.), Socijalne i temporalne usporedbe u različitim domenama tijekom adolescentne i odrasle dobi, Priopćenje na skupu XVI Dani Ramira Bujasa, Zagreb.

Djulbegovic, B., Hozo, I., Schwartz, A. i McMasters, K. M. (1999.), Acceptable Regret in Medical Decision Making. Medical Hypotheses, 53 (3): 253-259. doi:10.1054/mehy.1998.0020

Erikson, E. (1963.), Childhood and Society, New York, Norton.

Frijda, N. H., Kuipers, P. i ter Schure, E. (1989.), Relations among Emotion, Appraisal and Emotional Action Readiness. Journal of Personality and Social Psychology, 57 (2): 212-228. doi:10.1037//0022-3514. 57.2.212 
DRUŠ. ISTRAŽ. ZAGREB GOD. 21 (2012), BR. $3(117)$

STR. $651-670$

LACKOVIĆ-GRGIN, K.: ŽALJENJA:...
Frijda, N. H. (2004.), Emotion and Action. U: A. S. R. Manstead, N. Frijda i A. Fischer (ur.), Feelings and Emotions: The Amsterdam Symposium (str. 158-173), Cambridge, England, Cambridge University Press.

Gilovich, T. i Medvec, V. H. (1994.), The Temporal Pattern to the Experience of Regret. Journal of Personality and Social Psychology, 67 (3): 357-365. doi:10.1037//0022-3514.67.3.357

Gilovich, T., Medvec, V. H. i Kahneman, D. (1998.), Varieties of Regret: A Debate and Partial Resolution. Psychological Review, 105 (3): 602-605. doi:10.1037//0033-295X.105.3.602

Gilovich, T., Wang, R. X. F., Regan, D. i Nishina, S. (2003.), Regrets of Action and Inaction across Cultures. Journal of Cross-Cultural Psychology, 34 (1): 61-71. doi:10.1177/0022022102239155

Guttentag, R. i Ferrell, J. (2004.), Reality Compared with Its Alternatives: Age Differences in Judgment of Regret and Relief. Developmental Psychology, 40 (5): 764-775. doi:10.1037/0012-1649.40.5.764

Hampshire, S. (1960.), Thought and Action, London, Chato and Windus.

Hattiangadi, N., Medvec, V. H. i Gilovich, T. (1995.), Failing to Act: Regrets of Terman's Geniuses. International Journal of Aging and Human Development, 40 (3): 175-185. doi:10.2190/4U4E-N77B-PKJ2-CJXM

Havighurst, R. J. (1953.), Human Development and Education, New York, Longman.

Heckhausen, J., Wrosch, C. i Fleeson, W. (2001.), Developmental Regulation Before and After Deadline: The Sample Case of "Biological Clock" for Childbearing. Psychology and Aging, 16 (3): 400-413. doi:10.1037//0882-7974.16.3.400

Heckhausen, J. (1999.), Developmental Regulation in Adulthood, New York, Cambridge University Press.

Heckhausen, J. i Brim, O. G. (1997.), Perceived Problems for Self and Others: Self-Protection by Social Downgrading Throughout Adulthood. Psychology and Aging, 12 (4): 610-619. doi:10.1037//0882-7974. 12.4.610

Heckhausen, J. i Schulz, R. (1995.), A Life-Span Theory of Control. Psychological Review, 102 (2): 284-304. doi:10.1037//0033-295X.102.2.284

Inman, J. J. (2007.), Regret Regulation: Disentangling Self-Reproach from Learning. Journal of Consumer Psychology, 17 (1): 19-24.

Kahneman, D. (1995.), Varieties of Counterfactual Thinking. U: N. J. Roese i J. M. Olson (ur.), What Might Have Been: The Social Psychology of Counterfactual Thinking (str. 375-396), Mahwah, NJ: Lawrence Erlbaum Associates, Inc.

King, L. A. i Hicks, J. A. (2007.), Whatever Happened to "What Might Have Been"? Regrets, Happiness, and Maturity. American Psychologist, 62 (7): 625-636. doi:10.1037/0003-066X.62.7.625

Kinnier, R. T. i Metha, A. T. (1989.), Regrets and Priorities at Three Stages of Life. Counseling and Values, 33 (3): 182-193. doi:10.1002/j.2161007X.1989.tb00761.x

Klinger, E. (1977.), Meaning and Void: Inner Experience and the Incetives in People's Lives, Minneapolis, University of Minnesota Press. 
DRUŠ. ISTRAŽ. ZAGREB GOD. 21 (2012) BR. 3 (117),

STR. $651-670$

LACKOVIĆ-GRGIN, K.: ŽALJENJA:...
Lacković-Grgin, K. (2005.), Samoregulacija u odrasloj dobi. U: K. Lacković-Grgin i V. Ćubela Adorić (ur.), Odabrane teme iz psihologije odraslih (str. 25-65), Jastrebarsko, Naklada Slap.

Lacković-Grgin, K. (2007.), Motivacijska osnovica samoregulacije razvoja tijekom životnih tranzicija. Suvremena psihologija, 10 (2): 257-275.

Lacković-Grgin, K. i Penezić, Z. (2010.), Self-Regulation across Some Life Transitions. U: T. W. Miller (ur.), Handbook of Stressful Transitions across the Lifespan (str. 411-441), New York, Springer.

Landman, J. (1993.), Regret: Persistence of the Possible, New York, Oxford University Press.

Lazarus, R. S. i Folkman, S. (1984.), Stress, Appraisal and Coping, New York, Springer Publishing Company.

Lazarus, R. S. (1993.), From Psychological Stress to the Emotions: A History of Changing Outlooks. Annual Review of Psychology, 44: 1-22. doi:10.1146/annurev.psych.44.1.1

Lazarus, R. S. (1966.), Psychological Stress and the Coping Process, New York, McGraw-Hill.

Lee, W. (1971.), The Effects of Expected Value Differences and Expected Regret Ratio on Preference Strength. American Journal of Psychology, 84 (2): 194-204. doi:10.2307/1421356

Levinson, D. (1978.), The Seasons of a Man's Life, New York, Balantine Books.

Markus, N. i Nurius, P. (1986.), Possible Selves. American Psychologist, 41 (9): 954-969. doi:10.1037//0003-066X.41.9.954

Metha, A. T., Kinnier, R. T. i McWhirter, E. H. (1989.), A Pilot Study on the Regrets and Priorities of Women. Psychology of Women Quarterly, 13 (2): 167-174. doi:10.1111/j.1471-6402.1989.tb00994.x

Morrison, M. i Roese, N. J. (2011.), Regrets of the Typical American: Finding from a Nationally Representative Sample, http//spp.sagepub.com/ content/early/194850611401756 (28. 2. 2011.).

Penezić, Z. i Lacković-Grgin, K. (2001.), Važnost razvojnih ciljeva u adolescentnoj, srednjoj i starijoj životnoj dobi. Radovi-Razdio FPSP, 40 (17): 65-81.

Petz, B. (ur.) (2004.), Psihologijski rječnik, Jastrebarsko, Naklada Slap.

Plutchik, R. (1980.), Emotion: A Psychoevolutionary Synthesis, New York, Harper and Row.

Roese, N. J. (2005.), If Only, New York, Broadway Books.

Roese, N. J. i Summerville, A. (2005.), What We Regret Most ... and Why. Personality and Social Psychology Bulletin, 31 (9): 1273-1285. doi:10.1177/0146167205274693

Roseman, I. J., Wiest, C. i Swartz, T. S. (1994.), Phenomenology, Behaviors, and Goals Differentiate Discrete Emotions. Journal of Personality and Social Psychology, 67 (2): 206-211. doi:10.1037//0022-3514.67.2.206

Settersten, R. A., Jr. i Hagestad, G. O. (1996.a), What's the Latest? Cultural Age Deadlines for Family Transitions. Gerontologist, 36 (2): 178-188. doi:10.1093/geront/36.2.178 
DRUŠ. ISTRAŽ. ZAGREB GOD. 21 (2012), BR. $3(117)$

STR. $651-670$

LACKOVIĆ-GRGIN, K.: ŽALJENJA:...
Settersten, R. A., Jr. i Hagestad, G. O. (1996.b), What's the Latest? II. Cultural Age Deadlines for Educational and Work Transitions. Gerontologist, 36 (5): 602-613. doi:10.1093/geront/36.5.602

Snyder, C. R. (2002.), Hope Theory: Rainbows in the Mind. Psychological Inquiry, 13 (4): 249-275. doi:10.1207/S15327965PLI1304_01

Staudinger, U. M. (2001.), Life-Reflection: A Social-Cognitive Analysis of Life Review. Review of General Psychology, 5 (2): 148-160. doi:10. 1037//1089-2680.5.2.148

Stewart, A. J. i Vandewater, E. A. (1999.), "If I Had to Do Over Again...": Midlife Review, Midcourse Corrections, and Women's Well Being in Midlife. Journal of Personality and Social Psychology, 76 (2): 270-283. doi:10.1037//0022-3514.76.2.270

Taylor, G. (1985.), Pride, Shame and Guilt: Emotions of Self-Assessment, New York, Oxford University Press.

Tesser, A. (1988.), Toward Self-Evaluation Maintenance Model of Social Behavior. U: L. Berkowitz (ur.), Advances in Experimental Social Psychology (str. 181-227), New York, Academic Press.

Tesser, A., Millar, M. i Moore, J. (1988.), Some Affective Consequences of Social Comparison and Reflection Processes: The Pain and Pleasure of Being Close. Journal of Personality and Social Psychology, 54 (1): 49-61. doi:10.1037//0022-3514.54.1.49

van Dijk, W. W., van der Pligt, J. i Zeelenberg, M. (1999.), Effort Invested in Vain: The Impact of Effort on the Intensity of Disappointment and Regret. Motivation and Emotion, 23 (3): 203-220. doi:10.1023/ A:1021315314979

van Harreveld, F., van der Pligt, J. i Nordgren, L. (2008.), The Relativity of Bad Decisions: Social Comparison as a Means to Alleviate Regret. British Journal of Social Psychology, 47 (1): 105-117. doi:10.1348/ $014466607 X 260134$

Wrosch, C., Bauer, I. i Scheier, M. F. (2005.), Regret and Quality of Life Across the Adult Life Span: The Influence of Disengagement and Available Future Goals. Psychology and Aging, 20 (4): 657-670. doi:10. 1037/0882-7974.20.4.657

Wrosch, C. i Heckhausen, J. (2002.), Perceived Control of Life Regrets: Good for Young and Bad for Old Adults. Psychology and Aging, 17 (2): 340-350. doi:10.1037//0882-7974.17.2.340

Wrosch, C., Bauer, I., Miller, G. i Lupien, S. (2007.), Regret Intensity, Diurnal Cortisol Secretion, and Physical Health in Older Individuals: Evidence for Directional Effects and Protective Factors. Psychology and Aging, 22 (2): 319-330.

Wrosch, C., Scheier, M. F., Miller, G. E. i Schulz, R. (2003.), Adaptive Self-Regulation of Unattainable Goals: Goal Disengagement, Goal Reengagement, and Subjective Well-Being. Personality and Social Psychology Bulletin, 29 (12): 1494-1508. doi:10.1177/0146167203256921

Zeelenberg, M. i Pieters, R. (2004.), Beyond Valence in Customer Dissatisfaction: A Review and New Findings on Behavioural Responses to Regret and Disappointment in Failed Services. Journal of Business Research, 57 (4): 445-455. doi:10.1016/S0148-2963(02)00278-3 
DRUŠ. ISTRAŽ. ZAGREB GOD. 21 (2012)

BR. $3(117)$

STR. $651-670$

LACKOVIĆ-GRGIN, K. ŽALJENJA:...
Zeelenberg, M. i Pieters, R. (2007.), A Theory of Regret Regulation 1.0. Journal of Consumer Psychology, 17 (1): 3-18. doi:10.1207/s15327663 jcp1701_3

Zeelenberg, M., van Dijk, W. W., Manstead, A. S. R. i van der Pligt, J. (1998.), The Experience of Regret and Disappointment. Cognition and Emotion, 12 (2): 221-230. doi:10.1080/026999398379727

Zeelenberg, M. i Pieters, R. (1999.), Comparing Service Delivery to What Might Have Been: Behavioral Responses to Regret and Disappointment. Journal of Service Research, 2 (1): 86-97. doi:10.1177/109467 059921007

\section{Life Regrets: Phenomenology, Conceptualization and Research}

\author{
Katica LACKOVIĆ-GRGIN \\ Zadar
}

Regret is an unpleasant cognitive and emotional state. It appears as a consequence of mistakes (failures) in action, or of inaction on the way to achieve the goals. Philosophical, economic and psychological theories argue about the nature and causes of regret, one of the most frequent negative emotions. Successful coping with regret improves cognitive processes, but unsuccessful coping has a negative influence on motivation for directive action, resulting in life regrets and worse physical and mental health. The causes and context of experience of regret enable differences between regret on the one, and other negative emotions (disappointment, remorse, envy) on the other side. For this distinction, very important are the level of effort and feeling of responsibility. Descriptive studies show that the greatest regrets lie in the domains of education, career, romantic relationships, parenthood and self-concept, particularly if in some domains people perceived that they did not realize certain good opportunities. The level of regret depends on the subjective importance of the life domain, and on social and temporal comparisons. When a life review among older people results in regret, the intensity would be lower if they used lateral or downward comparisons. In self-regulation of regret, the role of internal control varies with age.

Keywords: life review, regret, coping, responsibility, effort, disappointment, social comparison, self-regulation 